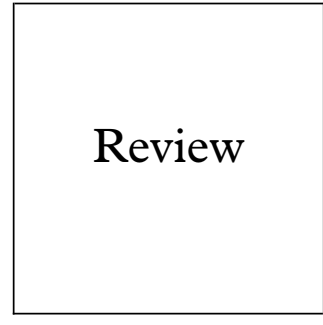

\title{
Oral sex and the transmission of viral STIs
}

\author{
Sarah Edwards, Chris Carne
}

Objective: To review the literature on the role of oral sex in the transmission of viral sexually transmitted infections (STIs).

Method: A Medline search was performed using the keywords oro-genital sex, and those specific to each infection. Further references from each article identified by Medline were also included, as were relevant references from "Current contents".

Conclusions: Oral sex is a common sexual practice among both heterosexual and homosexual couples. The evidence suggests that HIV transmission can take place through oro-genital sex from penis to mouth and vagina to mouth. Case reports describe apparent transmission from mouth to penis although this appears less likely. The risk of oro-genital transmission of HIV is substantially less than from vaginal and anal intercourse. Receptive oro-genital sex carries a small risk of human papillomavirus infection and possibly hepatitis $\mathrm{C}$, while insertive oro-genital contact is an important risk factor for acquisition of HSV 1. Oro-anal transmission can occur with hepatitis A and B. The transmission of other viruses may occur but is unproved. The relative importance of oral sex as a route for the transmission of viruses is likely to increase as other, higher risk sexual practices are avoided for fear of acquiring HIV infection. (Sex Transm Inf 1998;74:6-10)

Keywords: oral sex; viral STIs

For the purposes of this review the term oral sex is taken to include oro-genital and oro-anal sex but to exclude kissing. Oral sex is a common practice in both heterosexual and homosexual relationships. ${ }^{1}$ Vaginal intercourse remains the most commonly reported activity between heterosexual couples, although $72.9 \%$ of men and $66.2 \%$ of women had experienced cunnilingus, while $69.4 \%$ of men and $64 \%$ of women had experienced fellatio. ${ }^{1}$ This compares with much lower rates found by Kinsey in the 1940s and 1950s. ${ }^{23}$ Contemporary culture is approving of oro-genital sex, and during the 1970 s and 1980s premarital oral sex has increased dramatically ${ }^{4}$ and in one study more adolescent girls had received oral-genital stimulation than had vaginal intercourse. ${ }^{5}$ Among homosexual men there is evidence of declining rates of anal intercourse as a response to the HIV epidemic, ${ }^{6}$ and recent homosexual contact is more likely to be oro-genital or non ano-penetrative. ${ }^{1}$ Oral sex has therefore become a relatively more important route for the transmission of sexually transmitted infections (STIs). This and a subsequent article aim to review the literature on oral transmission of viral and non-viral STIs.

\section{Human immunodeficiency virus (HIV)}

HIV is found in semen, ${ }^{7}$ vaginal secretion, ${ }^{8}$ and, at much lower levels, in saliva. ${ }^{9}$ Apart from the level of HIV in saliva, other factors which may influence rates of transmission of HIV by oral sex are, firstly, the finding that other components of saliva inactivate the virus ${ }^{10}$ and, secondly, a lack of expression of potential receptors for HIV in oral mucosa. ${ }^{11}$ Thirdly, the presence of other pharyngeal infections may act as a cofactor in transmission. ${ }^{12}$ Although no clear evidence exists, it seems likely that inflammation of the mucosa and blood staining of saliva (which are particularly common with some oral manifestations of HIV) will influence the risk of transmission. Finally, microscopic physical trauma during oro-genital contact may also be important.

\section{HOMOSEXUAL TRANSMISSION}

Male to male

The original reports on the sexual transmission of HIV came from the early years of the American epidemic among homosexual men, when unprotected anal sex was common, and HIV infection was a virtual certainty if there was unprotected receptive anal intercourse with six or more different partners. ${ }^{13-15}$ These studies concluded that there was negligible risk of HIV acquisition from oro-genital sex, however it may be that the risk was obscured by the frequent practice of higher risk activities. Behaviour has changed since that time ${ }^{6}$ and there is an increasing number of case reports of transmission following orogenital sex between men. Seroconversion has occurred during receptive oro-genital sex both with $^{16}{ }^{17}$ and without ${ }^{18} 19$ ejaculation. Receptive oro-genital sex was a risk factor in three out of the five cases reported by Rozenbaum et al. ${ }^{20}$ However the other two patients denied any contact other than insertive fellatio and "deep kissing". Two further cases of HIV infection following insertive oro-genital sex have been reported; in one of these cases phylogenetic analysis supports the epidemiological data. ${ }^{21}$ In a study of primary HIV infection Schacker et al found that four of the 46 patients enrolled in the study reported having only unprotected oro-genital contact, including a documented case of infection after performing fellatio. ${ }^{22}$ If true, it seems that blood stained saliva must 
Table 1 Evidence for the transmission of viral STIs by oral sex

\begin{tabular}{|c|c|c|c|}
\hline Infection & Nature of risk & Evidence & References \\
\hline \multirow[t]{5}{*}{ HIV } & $\begin{array}{l}\text { Fellatio: } \\
\quad \text { oral partner }\end{array}$ & $\begin{array}{l}\text { Case reports: } \\
\text { with ejaculation } \\
\text { without ejaculation }\end{array}$ & $\begin{array}{l}16,17,20 \\
18,19,22,31\end{array}$ \\
\hline & penile partner & Case reports & $20,21,33,34$ \\
\hline & Cunnilingus & $\begin{array}{l}\text { Case report (between lesbian women, NB possible } \\
\text { under-reporting of bisexual behaviour) }\end{array}$ & 27 \\
\hline & oro-genital/oro-anal contact & Cohort studies & $23,25^{\star}, 26$ \\
\hline & (general) & $\begin{array}{l}\text { Higher reporting of oral contact between infected } \\
\text { partners }\end{array}$ & 29 \\
\hline \multirow[t]{3}{*}{ HSV } & to genital partner & Rising cases due to HSV 1 (esp women) & $38,39,40,41,42,48$ \\
\hline & & Case report after receptive fellatio & 46 \\
\hline & & Documented orogenital contact in HSV 1 cases & 47,48 \\
\hline \multirow[t]{5}{*}{$\mathrm{HPV}$} & to oral partner & Case reports of oral warts & $62,63,68$ \\
\hline & & Genital HPV types in oral mucosa & $64,65,66,67,74,75$ \\
\hline & & Studies suggestive of risk & $50,62,67,61$ \\
\hline & & Case report of oral bowenoid papulosis & 77 \\
\hline & to genital partner & Inc risk of cervical cancer with cunnilingus/fellatio & 69 \\
\hline \multirow[t]{3}{*}{ Hepatitis B } & Risk to oral partner in oro-anal sex & $\begin{array}{l}\text { Cohort study of prevalence and factors associated with } \\
\text { transmission }\end{array}$ & 82 \\
\hline & & Rectal lesions and HBsAg & 85 \\
\hline & & Cohort study & 81 \\
\hline \multirow[t]{2}{*}{ Hepatitis A } & Risk to oral partner in oro-anal sex & Higher rates of seropositivity in homosexual men & 90 \\
\hline & & Epidemics among homosexual men & 91,92 \\
\hline Hepatitis C & Risk with oro-genital contact & $\begin{array}{l}\text { Cohort study-marginal risk for oral sex with }>25 \\
\text { partners }\end{array}$ & 81 \\
\hline Molluscum contagiosum & To oral partner in oro-genital sex & Facial molluscum in AIDS patients & 97 \\
\hline Kaposi's sarcoma (HHV8) & Oro-anal sex & Association found in one study & 99 \\
\hline
\end{tabular}

^Study shows borderline significance.

have been involved. In the Amsterdam cohort study of 102 homosexual men, 11 men only admitted to oro-genital contact before seroconversion, although two of these changed their history at interview. ${ }^{23}$ The authors felt that the high proportion of men infected by this route was partly as a result of underreporting of higher risk activities in a group who were well informed about safer sex. This phenomenon has subsequently been found by others. ${ }^{24}$ The largest study of oral sex as a potential HIV risk was of 741 homosexual men in the Netherlands, which suggested that oro-genital contact alone was a risk for HIV acquisition, although this result was not statistically significant. ${ }^{25}$ However, Darrow et al were able to demonstrate that participants in a hepatitis B study had a higher risk of HIV infection from both oro-genital and oro-anal contact. ${ }^{26}$

\section{Female to female}

Perry et al have reported oro-genital transmission of HIV between women. ${ }^{27}$ However, it may be that not all cases of apparent female to female oral transmission are genuine as there appears to be underreporting of bisexual activity. ${ }^{28}$

\section{HETEROSEXUAL TRANSMISSION}

Fischl et al evaluated heterosexual partners of adults with AIDS and found higher reporting of oral sex among infected partners, but did not differentiate between male:female and female:male exposure. ${ }^{29}$

\section{Male to female}

In heterosexual intercourse there is a differential in transmission between the sexes, with a higher risk of women acquiring the infection..$^{30}$ Two cases of HIV transmission by fellatio (without ejaculation) with a seropositive drug user have been reported in Italy, ${ }^{31}$ while a larger study by Padian et al showed increased risk of transmission with increasing numbers of sexual contacts, irrespective of whether the contact was vaginal or oral. ${ }^{32}$

\section{Female to male}

Although there is known to be a lower overall risk of transmission from female to male, ${ }^{30}$ there is little information on the relative risk of different sexual practices. Cases of infection following oral sex have been reported, ${ }^{33}{ }^{34}$ one of which involved an impotent diabetic man infected by fellatio from a prostitute. ${ }^{33}$

\section{Herpes simplex virus}

Historically, genital herpes was predominantly caused by herpes simplex virus type 2 (HSV 2), ${ }^{35}$ but more recently there have been reports of both a rising incidence of new cases, ${ }^{37} 38$ and a rise in the proportion due to HSV 1 in various centres in the United Kingdom. ${ }^{38-40}$ This trend has also been reported in other countries with high or rising rates of genital herpes-for example, Japan, ${ }^{41}$ and also in the United States - a study by Wald et al published in $1994^{42}$ found $32 \%$ of primary herpes infections to be due to HSV 1 compared with the data from Corey et al in 1983 in which HSV 1 was isolated from only $10 \%$ of primary herpes. ${ }^{43}$ The increase in isolation of HSV 1 has been predominantly in women, and accounted for up to $79 \%$ of female isolates and $39 \%$ of male cases in one series. ${ }^{38}$ This would be compatible with the fact that both sexes report greater experience of cunnilingus than fellatio. ${ }^{1}$ However, further data from Sheffield suggest that misdiagnosis of mild HSV 1 infection in men may partly explain this discrepancy. ${ }^{44}$ Although some studies have reported that transmission of either viral type may be via oro-genital contact since concomitant pharyngitis may occur with primary genital infection, ${ }^{45}$ none has specifically looked at the role of oral contact as the sole route of transmission. The development of an acute HSV 1 pharyngitis in a homosexual man 
following insertive oral sex has recently been reported. ${ }^{46}$ Reports of HSV 1 transmission suggest that oral sex is the predisposing factor, although information on the practice of oro-genital sex is often absent from the case notes. ${ }^{48}$ The role of genito-genital spread of HSV 1 is probably less significant as genital HSV 1 infection recurs less often ${ }^{45}$ and is associated with less subclinical shedding of virus. ${ }^{49}$

\section{Human papillomavirus (HPV)}

Genital warts form a large proportion of the workload for many genitourinary medicine clinics, and are generally thought to be sexually transmitted. The seroprevalence of HPV antibodies rises with increasing numbers of sexual partners, ${ }^{50}{ }^{51}$ and the incidence of HPV lesions on the cervix is also correlated with greater numbers of sexual partners and earlier age of coitarche. ${ }^{52}$ However, studies of virgins have shown conflicting results, with no HPV detected either on analysis of tampons from virginal women ${ }^{53}$ or in a longitudinal serological study. ${ }^{54} \mathrm{HPV}$ DNA was detected by Pao et al in premarital checks of virgins raising the possibility of transmission by mechanisms other than penetrative intercourse, although in this series no HPV DNA was detected in the husbands to be. ${ }^{55}$ Transmission by fomites is plausible as HPV DNA has been isolated from equipment after examination of patients with genital warts, ${ }^{56}$ but transmission via this route is not proved and is thought to be unlikely. ${ }^{57}$ Hand-genital transmission is thought to occur ${ }^{58}$ and oro-genital transmission is therefore plausible. Vertical transmission (and viral persistence) is known to occur ${ }^{59}$ and is linked to juvenile respiratory papillomatosis. ${ }^{60}$ In a study comparing juvenile respiratory papillomatosis with adult onset disease, affected adults reported a higher frequency of oral sex than controls. ${ }^{61}$ The development of oropharyngeal warts is uncommon $^{62}{ }^{63}$ but when present a large proportion are due to "genital" HPV typesthat is, $6,11,16,18 .{ }^{64-67}$ One case report also temporally relates the development of an oral condyloma to cunnilingus with an infected partner. ${ }^{68}$ Some studies suggest oro-genital transmission ${ }^{5067}$ while another study found a slight increase in the risk of cervical cancer with fellatio and cunnilingus, although this may be confounded by the increased number of partners in the group reporting oral contact. ${ }^{69}$

Asymptomatic HPV is well recognised in genital sites ${ }^{50}$ and it is likely that asymptomatic infection in the mouth is commoner than manifest disease. Acetowhitening of the oral mucosa has been shown to be non-specific and should not be regarded as a diagnostic criterion for oral HPV infection, ${ }^{70}$ but HPV DNA has been identified in the mouth. ${ }^{71} 72 \mathrm{HPV}$ types 6 and 16 were identified in up to $24 \%$ of exfoliated oral mucosal cells in both normal children (suggesting persistence after perinatal infection) and in adults, ${ }^{71}$ and HPV was found in five out of 12 biopsies of normal tissue in another series. ${ }^{72}$ However, this was not confirmed in a further study in which 65 men and 111 women showed no evidence of oral HPV infection. ${ }^{73}$
HPV can also cause malignant change in the oral cavity and genital types (especially HPV 16) have been isolated from these lesions. ${ }^{74} 75$ However, HPV is clearly not the sole risk factor for oral cancer. Indeed, one study found a lower incidence of oral sex in cancer sufferers than in controls. ${ }^{76}$ Further evidence of oral pathology associated with HPV comes from the case report of a man being treated for Hodgkin's disease who had bowenoid papulosis on his penis and proved HPV associated severe epithelial dysplasia in his mouth, which the authors described as the first reported case of oral bowenoid papulosis. ${ }^{77}$

\section{Hepatitis viruses}

HEPATITIS B

Hepatitis B positivity has been known to be more frequent in STD clinic attenders, homosexual men, and prostitutes for many years, ${ }^{78-80}$ and is commoner in patients with more sexual partners or a past history of STI in both homosexual ${ }^{81-83}$ and heterosexual groups. ${ }^{83} \mathrm{An}$ tigen has been found in both semen and saliva ${ }^{84}$ and also in faeces, ${ }^{85}$ although this has not been confirmed by all investigators. ${ }^{86}$ Experimental transmission of hepatitis B has followed intradermal inoculation of saliva (in gibbons), but not after oral inoculation. ${ }^{87}$ Although sexual transmission is felt to be an important route for the spread of infection in heterosexuals ${ }^{88}$ the nature of the contact has not been addressed. More information is available on the relative risks of different sexual practices in homosexual men. The role of oroanal contact is probably important as a risk for transmission from anus to mouth. ${ }^{82}{ }^{85}$ Transmission may be from faeces or from asymptomatic rectal bleeding which has been reported in homosexual men ${ }^{85}$ and this would correlate with Kingsley and colleagues' finding of a higher risk from insertive than receptive anal intercourse. ${ }^{89}$ Receptive oro-genital contact with more than 25 partners was associated with hepatitis $\mathrm{B}$ infection in another series ${ }^{81}$ although the risk of transmission in this group may be confounded by the large number of partners. Kingsley et $a l^{89}$ and Schreeder et $a l^{82}$ failed to find an association between receptive oro-genital sex and HBV infection.

\section{HEPATITIS A}

As hepatitis A is an enteric pathogen and is excreted in the stools in high concentrations, it is not surprising that rates of infection are higher among homosexual men who report oro-anal contact. In Seattle the annual incidence was found to be $22 \%$ among seronegative individuals and there was a correlation between acquisition of hepatitis A and oro-anal contact, and also with increasing numbers of partners. ${ }^{90}$ Epidemic outbreaks affecting homosexual men have occurred ${ }^{9192}$ and these also suggest that the oral role in oro-anal contact is the predominant risk, while oro-penile contact is unimportant.

\section{HEPATITIS C}

Sexual transmission in hepatitis C infection is uncommon. ${ }^{93}{ }^{94}$ Transmission is linked to the 
presence of both hepatitis B and HIV which may act as cofactors, and a slightly higher prevalence of infection has been reported in homosexual men in one study. ${ }^{95}$ Receptive orogenital contact with more than 25 partners was marginally associated with infection (OR 2.4), with a similar association with more than 50 partners per year (OR 2.1) and more than 25 anal receptive partners (OR 1.9). ${ }^{81}$

\section{Miscellaneous}

MOLLUSCUM CONTAGIOSUM

These are commonly found on the genitalia in adults, ${ }^{96}$ and are frequently found on the face in homosexual men with AIDS. ${ }^{97}$ This could represent spread from the skin around the genital area during oro-genital contact.

\section{KAPOSI'S SARCOMA}

A new herpes virus designated human herpes virus 8 (HHV8) has been isolated from patients with Kaposi's sarcoma. ${ }^{98}$ One study has found oro-anal contact to be a risk factor for Kaposi's sarcoma in homosexual men. ${ }^{99}$

\section{Conclusion}

It is biologically plausible that transmission of HIV takes place through oro-genital sex from penis to mouth and vagina to mouth. This conclusion is supported by case reports. Further case reports suggesting transmission from mouth to penis are open to question on the basis that they are biologically less plausible unless blood stained saliva was involved. Epidemiological evidence indicates that orogenital sex poses substantially less risk of HIV infection than vaginal and anal intercourse.

Receptive oro-genital sex is also a risk factor for acquisition of human papillomavirus and possibly hepatitis C. Insertive oro-genital sex is a risk factor for acquisition of HSV 1 on the genitalia. Oro-anal sex, with transmission to the mouth, occurs with hepatitis A and B. Transmission of other viruses by oral sex is plausible but unproved.

The use of condoms or dental dams should be discussed with patients to minimise their risk of acquiring infection.

1 Johnson AM, Wadsworth J, Wellings K, Field J. Sexual attitudes and lifestyles. Oxford: Blackwell Scientific, 1994.

2 Kinsey AC, Pomeroy WB, Martin CE. Sexual behaviour in the human male. Philadelphia: WB Saunders, 1948.

3 Kinsey AC, Pomeroy WB, Martin CE, Gebhard PH. Sexual behaviour in the human female. Philadelphia: WB Saunders, 1953.

4 Gagnon JH, Simon W. The sexual scripting of oral genital contacts. Arch Sex Behav 1987;16:1-25.

5 Newcomer SF, Udry JR. Oral sex in an adolescent population. Arch Sex Behav 1985;14:41-6.

6 Winkelstein W, Samuel M, Padian NS, et al. The San Francisco men's health study. III Reduction in human immunodeficiency virus transmission among homosexual/bisexual men, 1982-6. Am f Public Health 1987;77:685-9.

7 Ho DD, Schooley RT, Rota TR, et al. HTLV-III in the semen and blood of a healthy homosexual man. Science 1984;226:451-3.

8 Wofsy CB, Cohen JB, Hauer LB, et al. Isolation of AIDS-associated retrovirus from genital secretions of women with antibodies to the virus. Lancet 1986;i:527-9.

9 Levy JA, Greenspan D. HIV in saliva. Lancet 1988;ii:1248.

10 Fultz PN. Components of saliva inactivate human immunodeficiency virus. Lancet 1986;ii:1215.

11 Hussain LA, Lehner T. Comparative investigation of Langerhans' cells and potential receptors for HIV in oral, genitourinary and rectal epithelia. Immunology 1995;85:475-84.

12 Murray AB, Greenhouse PRDH, Nelson WLC, et al. Coincident acquisition of Neisseria gonorrhoea and HIV from fellatio. Lancet 1991;i:830
13 Winkelstein W, Lyman D, Padian N, et al. Sexual practices and the risk of infection by the human immunodeficiency virus. The San Francisco men's study. $\mathscr{f} A M A$ 1987;257: $321-5$.

14 Kingsley LA, Kasb R, Rinabb CR, et al. Risk factors for seroconversion to human immunodeficiency virus among male homosexuals. Lancet 1987;i:345-8.

15 Melbye M, Biggar RJ, Ebbesen P, et al. Seroepidemiology of HTLV III in Danish homosexual men: prevalence, transmission and disease outcome. BMF 1984;289:573-5.

16 Lifson AR, O'Malley PM, Hessol NA, et al. HIV seroconversion in two homosexual men after receptive oral intercourse with ejaculation: implications for counselling concerning safe sexual practices. Am f Public Health 1990; concerning safe

17 Chen W, Samarasinghe PL. Allergy, oral sex and HIV. Lancet 1992;339:627-8

18 Edwards SK, White C. HIV seroconversion illness after orogenital contact with successful contact tracing. Int $\mathcal{F} S T D$ AIDS 1995;6:50-1.

19 Lane HC, Holmberg SD, Jaffe HW. HIV seroconversion and oral intercourse. Am f Public Health 1991;81:658.

20 Rozenbaum W, Gharakhanian S, Cardon B, Duval E, Coulaud JP. HIV transmission by oral sex. Lancet 1988;i: 1395 .

21 Bratt GA, Berglund T, Glantzberg BL, Albert J, Sandstrom E. Two cases of oral-to-genital HIV-1 transmission. Int $f$ STD AIDS $1997 ; 8: 522-5$.

22 Schacker T, Collier AC, Hughes J, Shea T, Corey L. Clini$\mathrm{cal}$ and epidemiologic features of primary HIV infection. Ann Intern Med 1996;125:257-64

23 Keet IPM, Albrecht van Lent N, Sandfort TG, Coutinho RA, van Grienvsen GJ. Orogenital sex and the transmission of HIV among homosexual men. AIDS 1992;6:223-6.

24 Doll LS, Harrison JS, Frey RL, et al. Failure to disclose HIV risk among gay and bisexual men attending sexually transmitted disease clinics. Am f Prev Med 1994;10:125-9.

25 van Grievsen GJP, Tielman RAP, Goudsmit J, et al. Risk factors and prevalence of HIV antibodies in homosexual men in the Netherlands. Am $f$ Epidemiol 1987;125:1048men

26 Darrow WW, Echenberg DF, Jaffe HW, et al. Risk factors for human immunodeficiency virus (HIV) infections in homosexual men. Am f Public Health 1987;77:479-83.

27 Perry S, Jacobsberg L, Fogel K. Orogenital transmission of human immunodeficiency virus. Ann Intern Med 1989;111 951-2.

28 Chu S, Hammett TA, Beubler JW. Update: epidemiology of reported AIDS cases in women who report sex only with other women United States 1980-1991. AIDS 1992;6: 518-9.

29 Fischl MA, Dickinson GM, Scott GB, et al. Evaluation of heterosexual partners, children and household contacts of adults with AIDS. $\mathscr{f} A M A$ 1987;257:640-4.

30 Padian NS, Shiboski SC, Jewell NP. Female to male transmission of human immunodeficiency virus. $\mathcal{F} A M A$ transmission of hin

31 Puro V, Narciso P, Girardi E, et al. Male to female transmission of human immunodeficiency vius by orogenital sex. Euro F Clin Microbial Infect Dis 1991;10:47.

32 Padian N, Marquis L, Francis DP, et al. Male to female transmission of human immunodeficiency virus. $\mathfrak{F A M} A$ 1987;258:788-90.

33 Spitzer PG, Weiner NJ. Transmission of HIV infection from a woman to a man by oral sex. N Engl F Med 1989;320:251

34 Quarto M, Germinario C, Troiano T, Fontana A, Barbuti S HIV transmission by fellatio. Eur f Epidemiol 1990;6:33940.

35 Smith IW, Peutherer JF, Robertson, DHH. Virological studies in genital herpes. Lancet 1976;ii: 1089.

36 Nahmias AJ, Dowdle WR, Naib ZM, et al. Genital infection with type 2 herpes virus hominis. $\mathrm{Br} \mathcal{F}$ Vener $\mathrm{Dis}$ with type 2 1969;45:294-8.

37 Department of Health. New cases seen at NHS genitourinary medicine clinics in England. Summary information from KC60. London: DoH Statistical Division, 1993.

38 Tayal SC, Pattman RS. High prevalence of herpes simplex virus type 1 in female anogenital herpes simplex in Newcastle upon Tyne 1983-92. Int $\mathcal{f}$ STD AIDS 1994;5:359-61.

39 Scoular A, Leask BGS, Carrington D. Changing trends in genital herpes due to herpes simplex virus type 1 in Glasgow, 1985-88. Genitourin Med 1990;66:226.

40 Barton IG, Kinghorn GR, Najem S, Al-Omar LS, Potter $\mathrm{CW}$. Incidence of herpes simplex virus types 1 and 2 isolated in patients with herpes genitalis in Sheffield. $B r \mathscr{F}$ Vener Dis 1982;58:44-7.

41 Ishiguro T, Ozaki Y, Matsunami M, Funakoshi S. Clinical and virological features of herpes genitalis in Japanese women. Acta Obstet Gynecol Scand 1982;61:173-6.

42 Wald A, Benedetti J, Davis G, et al. Antimicrob Agents Chemother 1994;38:174-6.

33 Corey L, Adams HG, Brown ZA, Holmes KK. Genital herpes simplex virus infections: clinical manifestations, course and complications. Ann Intern Med 1983;98:958-72.

44 Woolley PD, Kudesia G. Incidence of herpes simplex virus type- 1 and type- 2 from patients with primary (first attack) genital herpes in Sheffield. Int F STD AIDS 1990;1: 184-6.

45 Lafferty WE, Coombs RW, Bendetti J, Critchlow C, Corey L. Recurrences after oral and genital herpes simplex virus infection. N Engl f Med 1987;316:1444-9.

46 Jarvis RR, Goorney BP. Sexually acquired herpes simplex virus infection of the oropharyngeal cavity. Genitourin Med $1997 ; 73 ; 323-4$ 
47 Woolley PD. Value of examining the sexual partners of women suffering from initial genital herpes. Int $7 S T D$ AIDS 1991;2:365-6.

48 Edwards S, White C. Genital herpes simplex virus type 1 in women. Genitourin Med 1994;70:426.

49 Koelle DM, Benedetti J, Langenberg A, Corey L. Asymptomatic reactivation of herpes simplex virus in women after the first episode of genital herpes. Ann Intern Med 1992;116:433-7.

50 Schneider A. Pathogenesis of genital HPV infection. Genitourin Med 1993;69:165-73

51 Dillner J, Kallings I, Brihmer C, et al. Seropositivities to human papillomavirus types 16,18 , or 33 capsids and to human papillomavirus types 16,18 , or 33 capsids and to Chlamydia trachomatis are

52 Syrjanen K, Vayrynen M, Castren O, et al. Sexual behaviour of women with human papillomavirus (HPV) lesions of the uterine cervix. Br F Vener Dis 1984;60:243-8.

53 Fairley CK, Chen S, Tabrizi SN, et al. The absence of genital human papillomavirus DNA in virginal women. Int $f$ STD AIDS 1992;3:414-7.

54 Andersson-Ellstrom A, Dillner J, Hagmar B, Schiller J, Forssman L. No serological evidence fo non-sexual spread of HPV16 (letter). Lancet 1994;344:1435.

55 Pao CC, Tsai PL, Chang YL, Hsieh TT, Jin JY. Possible non-sexual transmission of genital papillomavirus infections in young women. Eur $\mathcal{F}$ Clin Microbiol Infect Dis 1993; 12:221-3.

56 Ferenczy A, Bergeron C, Richart RM. Human papillomavirus DNA in fomites on objects used for the management of patients with genital human papillomavirus infections. Obstet Gymecol 1989;74:950-4.

57 Puranen M, Syrjanen K, Syrjanen S. Transmission of genital human papillomavirus infections is unlikely through the floor and seats of humid dwellings in countries of high-leve hygiene. Scand F Infect Dis 1996;28:243-6.

58 Fairley CK, Gay NJ, Forbes A, Abramson M, Garland SM. Hand-genital transmission of genital warts? An analysis of prevalence data. Epidemiol Infect 1995;115:169-76.

59 Puranen M, Yliskoski M, Saarikoski S, Syrjanen K, Syrjanen $S$. Vertical transmission of human papillomavirus from infected mothers to their newborn babies and persistence of the virus in childhood. Am f Obstet Gynecol 1996:174:694-9.

60 Smith EM, Johnson SR, Cripe TP, Pignatari S, Turek L Perinatal vertical transmission of human papillomavirus and subsequent development of respiratory tract papillomatosis. Ann Otol Rhinol Laryngol 1991;100:479-83.

61 Kashima HK, Shah F, Lyles A, et al. A comparison of risk factors in juvenile-onset and adult onset recurrent respirafactors in juvenile-onset and adult onset recurrent

62 Clarke J, Terry RM, Lacey CN. A study to estimate the prevalence of upper respiratory tract papillomatosis in patients with genital warts. Int $\mathcal{F}$ STD AIDS 1991;2:114-5.

63 Kellokoski J, Srjanen S, Srjanen K, Yliskoski M. Ora mucosal changes in women with genital HPV infection. $f$ Oral Pathol Med 1990;19:142-8.

64 Grossman L, Wolnik L, Ikenberg $\mathrm{H}$, et al. Human papillomavirus types 6 and 11 DNA sequences in genital and laryngeal papillomas and in some cervical cancers. Proc Nat Acad Sci USA 1983;80:560-53.

65 de Villiers EM, Neumann C, Le J-Y, Weidauer H, zur Hausen $\mathrm{H}$. Infection of the oral mucosa with defined types of human papillomaviruses. Med Microbiol Immunol 1986; of human papil

66 Mounts P, Shah KV, Kashima H. Viral etiology of juvenile and adult onset squamous papilloma of the larynx. Proc Nat and adult onset squamous papill

67 Naghashfar Z, Sawada E, Kutcher MJ, et al. Identification of genital tract papilloma viruses HPV6 and HPV 16 in wart in the oral cavity. F Med Virol 1985;17:313-24.

68 Judson FN. Condyloma acuminatum of the oral cavity: a case report. Sex Transm Dis 1981;8:218-9.

69 Kataja V, Syrjanen S, Yliskoski M, et al. Risk factors associated with cervical human papillomavirus infections: a case control study. Am F Epidemiol 1993;138:735-45.

70 Kellokoski J, Syrjanen S, Kataja V, Yliskoski M, Syrjanen K. Acetowhite staining and its significance in diagnosis of oral
mucosal lesions in women with genital HPV lesions. 7 Oral Pathol Med 1990;19:278-83.

71 Jenison SA, Xiu-Ping Y, Valentine JM, et al. Evidence of prevalent genital-type human papillomavirus infections in prevalent genital-type human papillomavirus in
adults and children. F Infect Dis 1990;162:60-9.

72 Maitland NJ, Cox MF, Lynas C, et al. Detection of human papillomavirus DNA in biopsies of human oral tissue. $\mathrm{Br} f$ Cancer 1987;56:248-50.

73 van Doornum GJ, Hooykaas C, Juffermans LH, et al. Prevalence of human papillomavirus infections among hetero- sexual men and women with multiple sexual partners. $f$ Med Virol 1992;37:13-21

74 Brandsma JL, Steinberg BM, Abramson AL, Winkler B. Presence of human papilloma virus type 16 related sequences in verrucous carcinoma of the larynx. Cancer Res 1986;46:2185-8.

75 de Villiers EM, Weidauer H, Otto H, zur Hausen H. Papillomavirus DNA in human tongue carcinomas. Int $\mathcal{F}$ Cancer 1985;36:575-8.

76 Maden C, Beckmann AM, Thomas DB, et al. Human papillomaviruses, herpes simplex viruses, and the risk of oral cancer in men. Am 7 Epidemiol 1992;135:1093-102.

77 Kratchovil FJ, Cioffi GA, Auclair PL, Rathbun WA Virus-associated dysplasia (bowenoid papulosis?) of the Virus-associated dysplasia (bowenoid papulosis?) of the
oral cavity. Oral Surg Oral Med Oral Pathol 1989;68:312-6.

78 Fulford KWM, Dane DS, Catterall RD, Woof R, Denning JV. Australia antigen and antibody among patients attending a clinic for sexually transmitted diseases. Lancet 1973; 1470-2.

79 Jeffries DJ, James WH, Jefferiss FJG, MacLeod KG, Willcox RR. Australia (hepatitis associated) antigen in patients attending a venereal disease clinic. BMf 1973;2:455-6.

80 Henigst W. Sexual transmission of infections associated with hepatitis B antigen. Lancet 1973;ii: 1395.

81 Osmond DH, Charlebois E, Sheppard HW, et al. Comparison of risk factors for hepatitis C and hepatitis B infection in homosexual men. F infect Dis 1993;167:66-71.

82 Schreeder MT, Thompson SE, Hadler SC, et al. Hepatitis B in homosexual men: prevalence of infection and factors in homosexual men: prevalence of infection and

83 Hentzer B, Skinhoj P, Hoybye G, et al. Viral hepatitis in a venereal clinic population. Scand 7 Infect Dis 1980;12:245-9.

84 Heathcote J, Cameron CH, Dane DS. Hepatitis B antigen in saliva and semen. Lancet 1974;i:71-3.

85 Reiner NE, Judson FN, Bond WW, Francis DP, Petersen NJ. Asymptomatic rectal mucosal lesions and hepatitis B surface antigen at site of sexual contact in homosexual men with persistent hepatitis B virus infection. Ann Intern Med 1982;96:170-3.

86 Feinman SV, Berris B, Rebane A, Sinclair JC, Wilson S, Wrobel D. Failure to detect hepatitis B surface antigen (HBsAg) in feces of HBsAg positive persons. F Infect Dis 1979;140:407-10.

87 Scott RM, Snitbhan R, Bancroft WH, Alter HJ, Tingpalapong $M$. Experimental transmission of hepatitis $B$ virus by semen and saliva. F Infect Dis 1980;142:67-71.

88 Struve J, Giesecke J, Lindh G, Weiland O. Heterosexual contact as a major route for transmission of acute hepatitis contact as a major route for transmission

89 Kingsley LA, Rinaldo CR, Lyter DW, et al. Sexual transmission efficiency of hepatitis B virus and human immunodeficiency virus among homosexual men. $\mathscr{F} A M A$ 1990;264: 230-24.

90 Corey L, Holmes KK. Sexual transmission of hepatitis A in homosexual men. N Engl f Med 1980;302:435-8.

91 Christenson B, Brostrom C, Bottiger M, et al. An epidemic outbreak of hepatitis A among homosexual men in Stockholm. Hepatitis A, a special hazard for the male homosexual subpopulation in Sweden. Am f Epidemiol 1982;116:599-607.

92 Henning KJ, Bell E, Braun J, Barker ND. A communitywide outbreak of hepatitis A: risk factors for infection among homosexual and bisexual men. Am f Med 1995;99: among

93 Melbye M, Biggar RJ, Wantzin P, et al. Sexual transmission of hepatitis C virus: cohort stuy (1981-9) among European homosexual men. BMF 1990;301:210-2.

94 Tor J, Llibre JM, Carbonell M, et al. Sexual transmission of hepatitis $C$ virus and its relation with hepatitis $B$ virus and HIV. BMF 1990;301:1130-3.

95 Tedder RS, Gilson RJC, Briggs M, Loveday C, Cameron $\mathrm{CH}$. Hepatitis $\mathrm{C}$ virus: evidence for sexual transmission. BMF 1991;302:1299-302.

96 Douglas JM. Molluscum contagiosum. In: Holmes KK, Mardh P-A, Sparling PF, Weisner PJ, eds. Sexually transmitted diseases. 2nd ed. New York: McGraw-Hill, 1990.

97 Schwartz JJ, Myskowski PL. Molluscum contagiosum in patients with human immunodeficiency virus infection. $\mathcal{F}$ Am Acad Dermatol 1992;27:583-8.

98 Chang Y, Cesarman E, Pessin MS, et al. Identification of herpes-like DNA sequences in AIDS-associated Kaposi's sarcoma. Science 1994;266:1865-9.

99 Beral V, Bull D, Darby S, et al. Risk of Kaposi's sarcoma and sexual practices associated with faecal contact in homosexual or bisexual men with AIDS. Lancet 1992;339: $632-5$ 